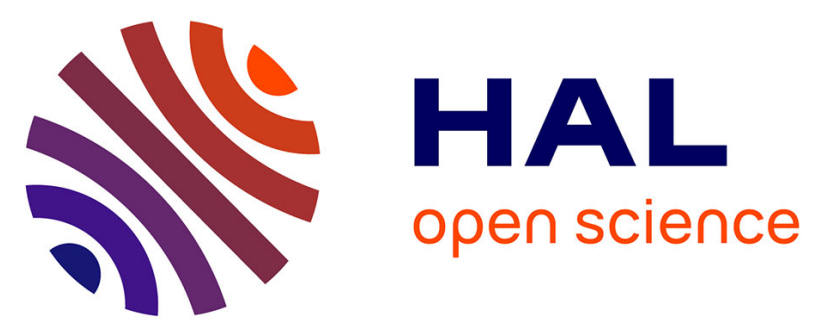

\title{
A CHEMICAL OXYGEN-IODINE LASER WITH A HIGH WATER VAPOR CONTENT
}

N. Gerasimenko, V. Yeroshenko, V. Kalinovski, V. Konovalov, I. Krukovski, V. Nikolaev, L. Shornikov

\section{- To cite this version:}

N. Gerasimenko, V. Yeroshenko, V. Kalinovski, V. Konovalov, I. Krukovski, et al.. A CHEMICAL OXYGEN-IODINE LASER WITH A HIGH WATER VAPOR CONTENT. Journal de Physique IV Proceedings, 1991, 01 (C7), pp.C7-672-C7-672. 10.1051/jp4:19917180 . jpa-00250859

\section{HAL Id: jpa-00250859 https://hal.science/jpa-00250859}

Submitted on 1 Jan 1991

HAL is a multi-disciplinary open access archive for the deposit and dissemination of scientific research documents, whether they are published or not. The documents may come from teaching and research institutions in France or abroad, or from public or private research centers.
L'archive ouverte pluridisciplinaire HAL, est destinée au dépôt et à la diffusion de documents scientifiques de niveau recherche, publiés ou non, émanant des établissements d'enseignement et de recherche français ou étrangers, des laboratoires publics ou privés. 


\section{A CHEMICAL OXYGEN-IODINE LASER WITH A HIGH WATER VAPOR CONTENT}

N.N. GERASIMENKO, V.A. YEROSHENKO, V.V. KALINOVSKI, V.V. KONOVALOV, I.M. KRUKOVSKI, V.D. NIKOLAEV and L.N. SHORNIKOV

All-Union Scientific Research Institute of Experimental Physics, Arzamas-16, Gorky Region 607200, USSR

\section{Abotract}

To ohook whether it is poosible to make tho conotruntion of an oxygerifiudire lmagr loss complioated and to givo up In the Iuture a oold wotor trap, we Invegtigated the poesibility for CoId oparation at is kh oontent of tho wator vapor in the aotive mentum.

With the oxygon pressure Inoragse between $0.5 \ldots . .5$ Tors and tha water vapor content between $0.3 \ldots 1.0$ Turr at the constant lodiue oonoentration 10 mToxr, the generation power inoraged from 1.0 t.0 $4.5 \mathrm{~kW}$, eaturation of the radiation power dependense on the oxyken preseutic war not obeerved. Hito vitput pewox an a Punntiom of water vapox

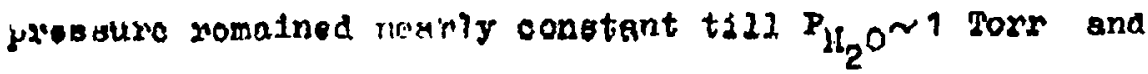
then rapialy docroaood.

The lasting rogiton was $0.5 \ldots 3.5$ on downgtream of the lodine injeotor. We obsexvod molecular jodino to diseoclate almoot immorilatipiy $\left(\tau^{\prime}\right.$ as $\left.<0 \mu \mathrm{s}\right)$ artor injeotion into alnglet oxygen flow in contradjction with kinetio model. The aotive medium guin varied with tsme ponmonotonioally in the exporiment where the injocted moleoular lodino conoontration morictoricully deoneand. 